\title{
Historic Landscape vs. Urban Commodity?: The Case of Yedikule Urban Gardens, İstanbul
}

\author{
Tarihsel Peyzaj mı Kentsel Meta mı?: İstanbul Yedikule Bostanları Örneği*
}

\author{
Elifnaz DURUSOY, ${ }^{1}$ Duygu CIHANGER ${ }^{2}$
}

\section{ABSTRACT}

Urban gardens are formed by an interrelation of natural, social, and economic dynamics over time. At the interface of the urban and rural, they provide important social and psychological benefits beyond their explicit environmental and ecological value. By providing opportunities for urban farming and agricultural production, the gardens offer a rejuvenation of collectivity within communities. However, these unique characteristics also make them some of the areas most vulnerable to the irrepressible growth of urban development. Cultural conservation and social inclusion in the gardens of İstanbul have been challenged by economic development in recent decades. Hence, they provide apt examples of the hardships faced when attempting to sustain urban gardens during periods of urban growth. The present study is focused particularly on the Yedikule Urban Gardens in İstanbul, emphasizing both destruction and development in the context of physical, natural, economic, and social change. "New" planning and conservation processes are proposed, and a framework for the integration of urban farming and rural production into changing urban environments is provided with the aim of conserving cultural and productive landscapes. This concern also presents an introductory discussion for the significance of urban green commons in Turkey. Keywords: Urban garden; change; urban green commons; Yedikule Urban Gardens; i̇stanbul.

ÖZ

Kent bahçeleri çeşitli doğal, toplumsal ve ekonomik dinamiklerin tarihsel birikimleri ve birbiriyle etkileşimleriyle biçimlenirler. Kırın ve kentin arayüzünü oluşturan bu nadir alanlar aynı zamanda oldukça açık olan çevresel ve ekolojik değerlerinin ötesinde toplumlar ve kentler için önemli sosyal ve psikolojik faydalara sahiptir. Yarattıkları kentsel tarım ve üretim uygulamaları süreçleriyle, kentlerdeki tekdüze "kentsel" yaşam tarzına sundukları kaçış yollarıyla topluluklar arasında birlikteliği ve ortaklıkları geliştirme potansiyeli taşımaktadırlar. Bu az görünen nitelikler, kent bahçelerini aynı zamanda kentlerin korunması en zor ve en hassas alt birimlerinden kılmaktadır. Nitekim son zamanlarda önüne geçilemez hale gelen kentsel büyüme kent bahçeleri ve insanlar arasındaki ilişkiyi tehdit etmektedir. Istanbul'daki kent bahçeleri de son yıllarda kültürel koruma, ekonomik büyüme ve sosyal katılım gibi konularda çeşitli çelişkilerle yüzleşmektedir. Bu sebeple, yukarıda bahsi geçen kentsel büyüme gerçeği ve korumada yaşanan zorluklara uygun bir örnek teşkil ederler. Bu çalışma özelinde Istanbul'daki önemli kent bahçelerinden olan Yedikule Bostanları'nda gerçekleşen yıkım ve gelişme kavramları, mekanda yaşanan değişimin fiziksel, doğal, ekonomik ve toplumsal bağlamları içerisinde değerlendirilmektedir. Bu çalışma yaşanan kentsel değişim ve büyüme süreçlerinde kentsel tarım, kırsal üretim ve kültürel-üretken peyzaj alanlarının eklemlenmesi adına genel bir çerçeve sunmaktadır. Bu bakış açısı Türkiye'de yeni oluşan kentsel yeşil ortaklıkların da tartışmaya açılmasını hedeflemektedir.

Anahtar sözcükler: Kent bahçesi; değişim; kentsel yeşil ortaklıklar; Yedikule Bostanları; istanbul.

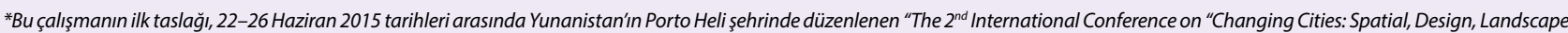
\& Socio-economic Dimensions" adlı konferansta "Destruction of a Relict Landscape for a New Community: The Case of Yedikule Urban Gardens, Istanbul" başlığı ile sözlü olarak sunulmuştur.

'Department of Architecture, Yıldız Technical University, İstanbul, Turkey ${ }^{2}$ Department of City and Regional Planning, Middle East Technical University, Ankara, Turkey

Article arrival date: August 28, 2015 - Accepted for publication: January 17, 2016

Correspondence: Elifnaz DURUSOY. e-mail: e.durusoy@hotmail.com

๑) 2016 Yıldız Teknik Üniversitesi Mimarlık Fakültesi - ๑ 2016 Yıldız Technical University, Faculty of Architecture 


\section{Introduction}

The unrestrainable expansion of recent urban formations and their negative consequences on nature is a widely-discussed topic today as cities worldwide are facing rapid social, economic, environmental changes and cultural transformations. Although there is no official statistics on the rate of this conversion, a substantial amount of open areas including fertile agricultural lands, city orchards, arable fields, cultivated urban lots as well as parks are being transformed into different land uses. ${ }^{1,2}$ In other words, urbanization spreads towards 'unbuilt' areas reducing the relationship between people and nature, decreasing the green open areas and damaging the agricultural production. In this context, under management of significant landscapes within the urban areas has become a critical issue recently. Therefore, to preserve these landscapes as public and common areas in cities and to meet the food requirements for a sustainable future emerge as a fundamental problem today since they face pressures in terms of their transformation and destruction. These open, green and sometimes productive urban landscape units should be conserved in a sensible manner through the proper use of urban planning, conservation and architectural approaches.

Urban gardens, as one of these landscape units, have been shaped by relationships between natural, social and economic dynamics through long periods of time. They are inevitably subjected to the urban growth and expansion processes in cities as well. Throughout history, these gardens have been the individual green areas in which people grow plants, vegetables, fruits for their own consumption as well as for small-scale commerce. This marked one of the basic characteristic sections of cities and urban landscape. The gardens have played vital roles such as feeding cities, generating income and recycling urban wastes for the lives of people since the times human beings settled down and started to produce their own food in a sustainable way. ${ }^{3}$ Besides these environmental and ecological amenities, urban gardens have also provided important societal and psychological benefits to human societies, which enrich human social life for "cultural diversity and human creativity" [URL-1]. ${ }^{4}$ They have provided places of recreation and activity for people to walk, cycle, play, rest and socialize that helps physical and mental health of public to improve. Additionally, since they reflect "combined works of nature and humankind by expressing a long and intimate relationship between peoples and their natural environment", urban gardens can easily be listed as a subheading under the "cultural landscapes" criteria of UNESCO. ${ }^{5}$ Thereby, as es-

\footnotetext{
Kaldjian, 2004, s.285-286.

2 Başer et al., 2010, s.106-107.

4 Ricci, 2008, s.67

5 UNESCO, 2009, s.19.
}

sential public landscapes, urban gardens not only have the potential of breaking monotonous everyday life in cities with urban farming production opportunities in ecological and planning contexts, but also enrich collective relationships within communities in economic and social perspectives. Urban gardens as interfaces of urban and rural are also the witnesses of biological and cultural diversity of the past. As bridges carrying the traces of the past to present, they are significant urban areas for protection.

However, within the $21^{\text {st }}$ century cities, the relationship between people and nature has been altered with the transformation of lifestyle and expansionist urbanism implications all around the globe. Hence, as one of the most vulnerable sections of cities, urban gardens have started to be perceived as void, vast and inessential pieces of cities to be transformed. Especially in developing countries with a rapid population growth, they have started to be seen as the opportunities for new constructions. Therefore, the main concern of this paper is to identify the meaning of an urban garden with the help of the case Yedikule Urban Gardens. By underlining both the "destruction" and "development" sides of the story of Yedikule Urban Gardens in physical, natural, economic and social facets of transformation in a chronological manner, it tries to show the recent conditions of the urban gardens of Istanbul. This study suggests a general proposal for urban gardens that integrates urban farming, rural production as well as conservation of cultural and productive landscapes into the rapidly changing urban dynamics.

\section{Urban Gardens of Istanbul}

Istanbul; the capital city of three great empires, Roman, Byzantine and Ottoman, has a long history of agriculture in urban settlements. The city has hosted a number of urban gardens or with their local Turkish names 'bostan- $\mathrm{s}^{\prime}$ that have used for urban farming by people called 'bostanci"7 through its built fabric (Figure 1). Urban gardens of Istanbul are founded close to the center of the city and mostly spread around productive sources of water and natural springs of the city. ${ }^{8,9}$

These gardens were intensively, expertly and sustainably cultivated to maximize harvests through clever and efficient management of space and resources. They were

\footnotetext{
6 Tanyeri-Erdemir, 2009, s.6. "The Turkish term commonly used for this type of orchards is 'bostan', which literally indicates areas of agricultural production of vegetables (cucumbers, tomatoes, carrots etc.), legumes and herbs (lettuce, parsley, mint, arugula etc.), excluding orchards of fruit-bearing trees and fields of grains. 'Bostan's are usually small plots of lands, usually around four to five acres, and are tended by relatively few individuals, mostly no more than the members of a single family, so denotes smallscale agricultural production with a commercial purpose."

7 Tanyeri-Erdemir, 2009, s.6. 'Bostancı' refers to the individual who takes care of the occupation of 'bostan'.

8 Kaldjian, 2004, s.286, 290-291.

9 Kıvılcım Çorakbaş et al., 2014, s.35-37.
} 


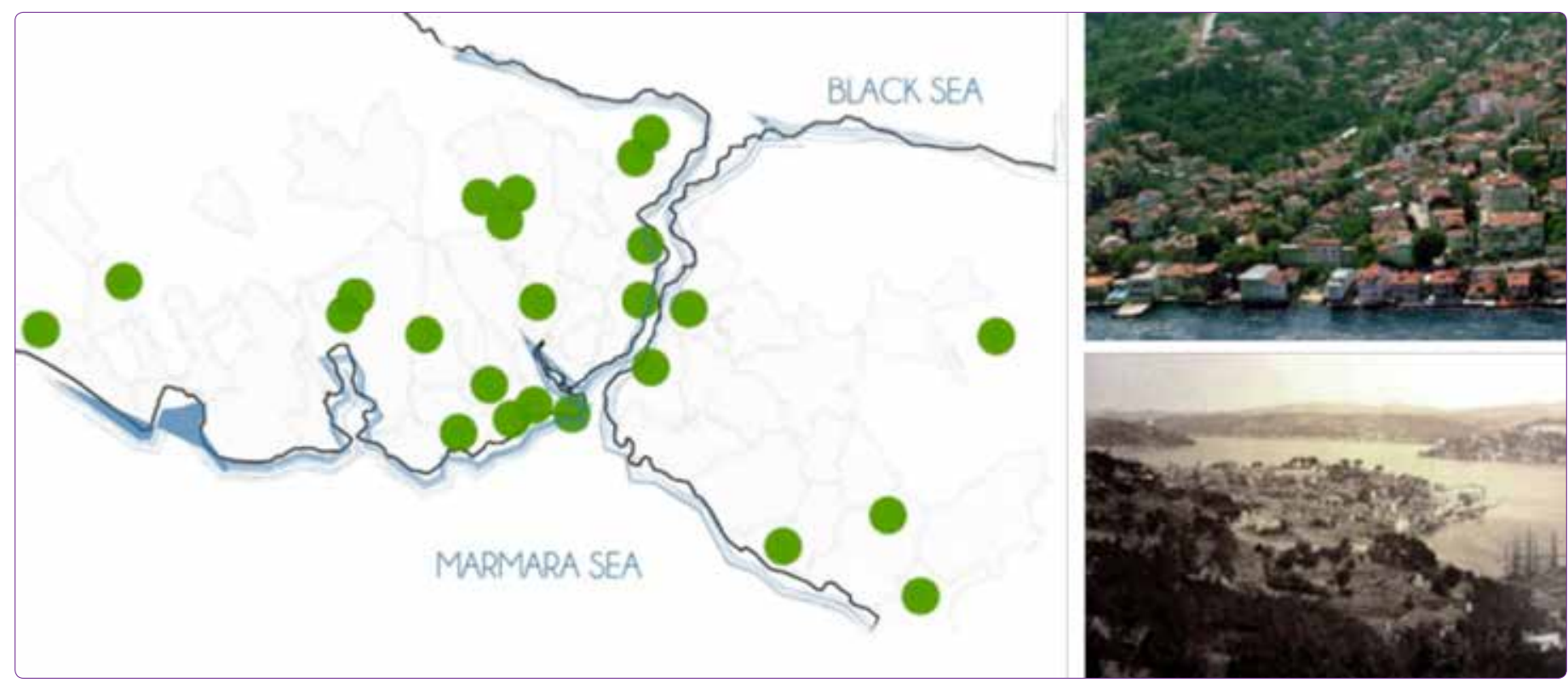

Figure 1. (Left) Distribution of urban gardens through Istanbul, prepared with the help of information coming from the records of Kaldjian and Google Earth (Prepared by Authors) (Right-Top) Kuzguncuk Urban Gardens, 2010 [URL-2] (Right-Bottom) Arnavutköy Urban Gardens, Date Unknown [URL-3].

firstly mentioned in old Byzantine recordings during $5^{\text {th }}$ century AD. ${ }^{10}$ Following this, they were underlined in the early farming, food production and consumption recordings of ancient Byzantium - Geoponica that is considered to be written and compiled in between 944-59 AD, over a thousand years ago. ${ }^{11-13}$ Then, Evliya Celebi, the $17^{\text {th }}$ century Ottoman traveler, recorded 4395 gardens that approximately equal to 16,500 square meter fertile green lands within the city. ${ }^{14}$ Eremya Celebi Komurcuyan, an Ottoman poet, traveler and historian, also noted the same garden crops that vegetable production was widespread throughout the city and a part of the daily life of several neighborhoods. ${ }^{15,16}$ At the end of the $19^{\text {th }}$ century, more than a hundred of clusters of urban gardens were recorded within Istanbul. ${ }^{17}$

In addition to the physical and historical aspects, urban gardens of Istanbul are also valuable since they supported the gardening tradition - 'bostancilık' of the city. Urban gardens of the city can easily be identified as one of the most crucial parts of Istanbul's identity such that different neighborhoods have known with their gardens and their special crops: Arnavutkoy has been known with its aromatic strawberries and cherries; Cengelkoy has been popular with its small cucumbers etc. ${ }^{18}$ These features of products have made urban gardens of Istanbul one of the first pref-

\footnotetext{
${ }^{10}$ Koçu, 1963, s.2971-2972.

${ }^{11}$ Ricci, 2008, s.67.

12 Tanyeri-Erdemir, 2009, s.6.

${ }^{13}$ White et. al., 2015, s.7.

${ }^{14}$ Kaldjian, 2004, s. 290.
}

erences of farmers and consumers from all around the city. Moreover, the motifs 'bostan' and 'bostancl' are so deeply attached into the daily life of Turkish people that a number of sayings and rhymes such as "Bostan korkuluğu" (Bostan scarecrow), "Bostan yeşil iken pazarlık yapılmaz" (Bargain is not made during bostan is green), "Bostana dadanan eşeğin, kuyruğu kulağı olmaz" (Donkey, visiting the bostan frequently, would have no tear and ears), "Kov bostancı danayı, yemesin lahanayı" (Bostancı, send the calf away, don't let it to eat the cabbage), etc. have popularly been used for long times in social life. To extent, urban gardens of Istanbul can be seen as significant visible stores for comprehending the old patterns of urban agriculture. Therefore, thanks to their above mentioned environmental, historical, documentary, aesthetic and artistic, social and cultural, technologic, functional and economic values, urban gardens of Istanbul can easily be recognized as the center of accumulated culture and knowledge that have developed over centuries and now serve as organic models for urban farming.

\section{Yedikule Urban Gardens}

Yedikule Urban Gardens (Yedikule 'Bostan's) that took its name from seven towers at the south end of the old city walls of Theodosius can be regarded as one of the few remaining significant green fields of the densely built and populated historic peninsula in Istanbul. Having been a critical section of the universally protected UNESCO World Heritage Site of Istanbul along the Theodosius Walls, Yedikule Urban Gardens have managed to survive up to the present as the earliest agricultural remaining lands with 


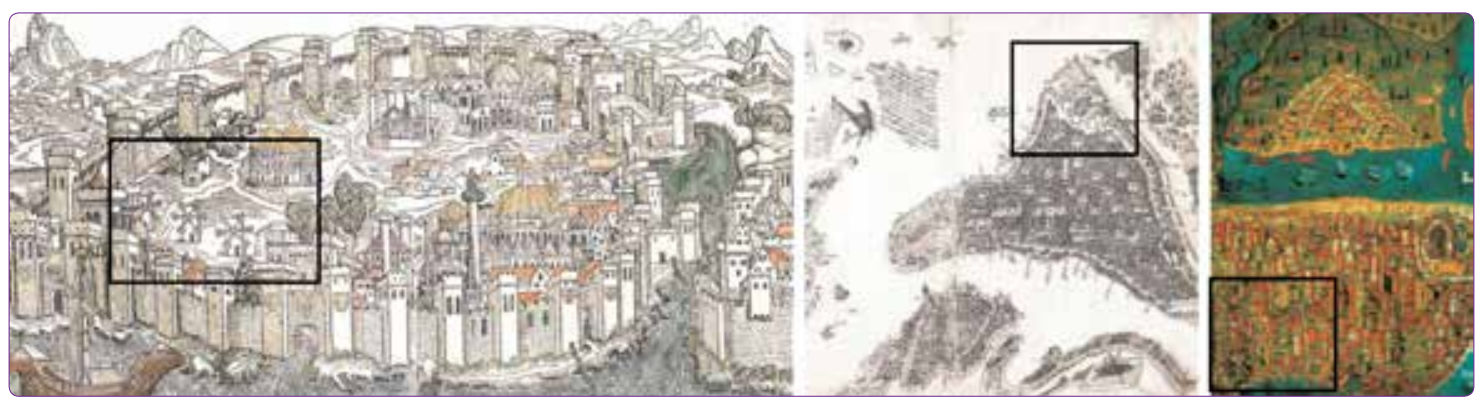

Figure 2. (Left) Ancient view of Istanbul drawn by Hartman Schedel, 1493 (Kayra, 1990: 65) (Middle) Map of Istanbul drawn by Lokman Çelebi, 1584 (Kayra, 1990: 74) (Right) Gravure of Istanbul drawn by of Matrakci Nasuh, 1534 [URL-4].

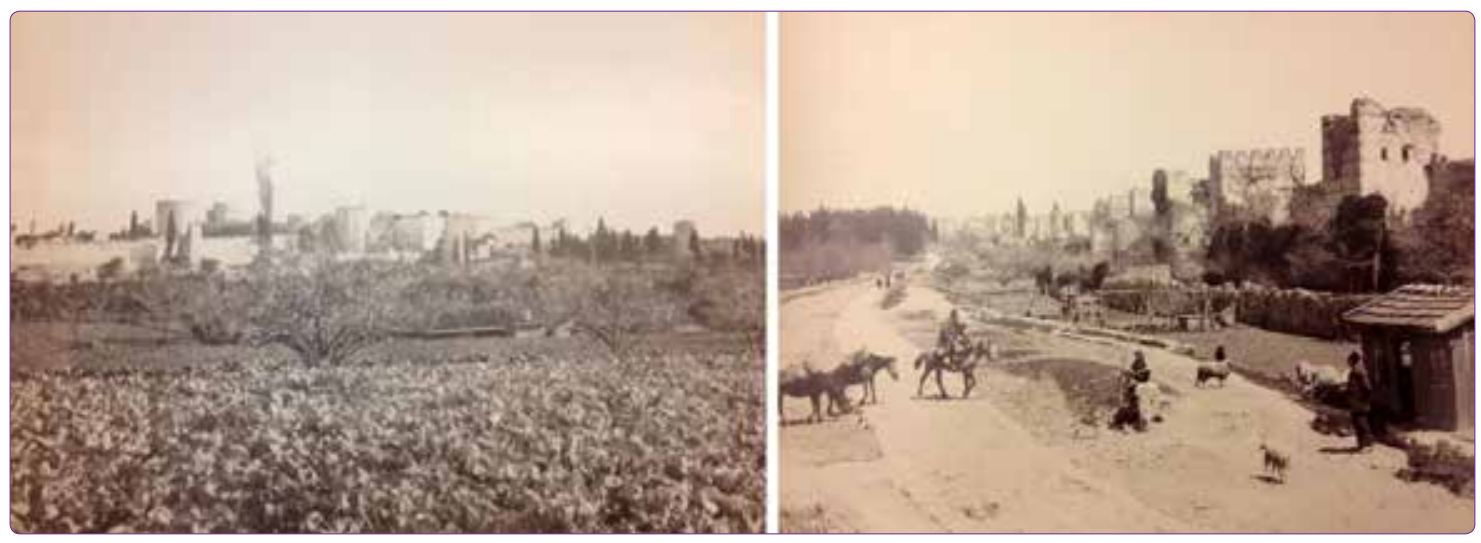

Figure 3. Old pictures showing Yedikule Urban Gardens [URL-5].

their more than 1500 years of history [URL-1]. ${ }^{19,20}$ Historical maps, drawings, gravures and old photographs shows that these gardens constituted an integral part of the historic built pattern as urban agricultural landscapes and formed with the boundaries of the historic city along with the Land Walls system (Figure 2 and Figure 3). In other words, it can easily be concluded that Yedikule Urban Gardens have supplied Istanbul since Byzantine times as a direct link to the past besides their importance as a component of the UNESCO heritage site today. Therefore, the use of the urban gardens along the Theodosius fortifications for market gardening of vegetables can be introduced as a continuous tradition that has roots going back to hundreds of years.

Looking back its history in short, Theodosius Walls that mark the borders of Yedikule Urban Gardens today was originally designed to protect Constantinople from invaders on the western edge. ${ }^{21-23}$ These walls once formed a strong barrier to the city were remained mostly unspoiled during Ottoman Period and agricultural activities around

\footnotetext{
19 Koca, 2014, s.58.

20 "Historic areas of Istanbul" was declared as a world heritage site by UNESCO in 1985 with the criteria (i), (ii), (iii) and (iv). The section including the Urban Gardens of Yedikule along Theodosius Walls is
}

the wall were attested by the final decision of the emperor. $^{24}$ There is a reference allowing farmers to store agricultural tools inside the towers of the walls. ${ }^{25}$ After this period of time, with the conquest of Istanbul in 1453, Fatih Sultan Mehmet settled a number of people to the neighborhood of Yedikule who were engaged in agricultural activity. ${ }^{26}$ Following this, a number of urban gardens along and outside the wall expanded northwards by forming a special linear green spine in $17^{\text {th }}$ century.

Today Istanbul began to enlarge through its peripheriesincluding Yedikule after years of industrialization. Nonetheless, the newly built areas were cut through with the walls after the regulations operated by Henry Prost. Following the declaration of the historic areas of Istanbul as a world heritage site, a large-scale restoration program was initiated on the city Walls of Theodosius for people and visitors to comprehend the area better. Connected with the restoration project, the open area corridor along Theodosius Walls was revaluated and a number of urban gardens were re-functioned into different uses such as recreation and parks. ${ }^{27}$ Most of the urban gardens in Yedikule have continued their functions with no drastic change from the end of the Ottoman Empire until the second half of the

\footnotetext{
${ }^{24}$ Tanyeri-Erdemir, 2009, s.7. $\quad{ }^{26}$ Kaldjian, 2009, s.10.

${ }^{25}$ Tanyeri-Erdemir, 2009, s.7. $\quad{ }^{27}$ Kıvılcım Çorakbaş et al., 2014, s.16-17, 32.
} 


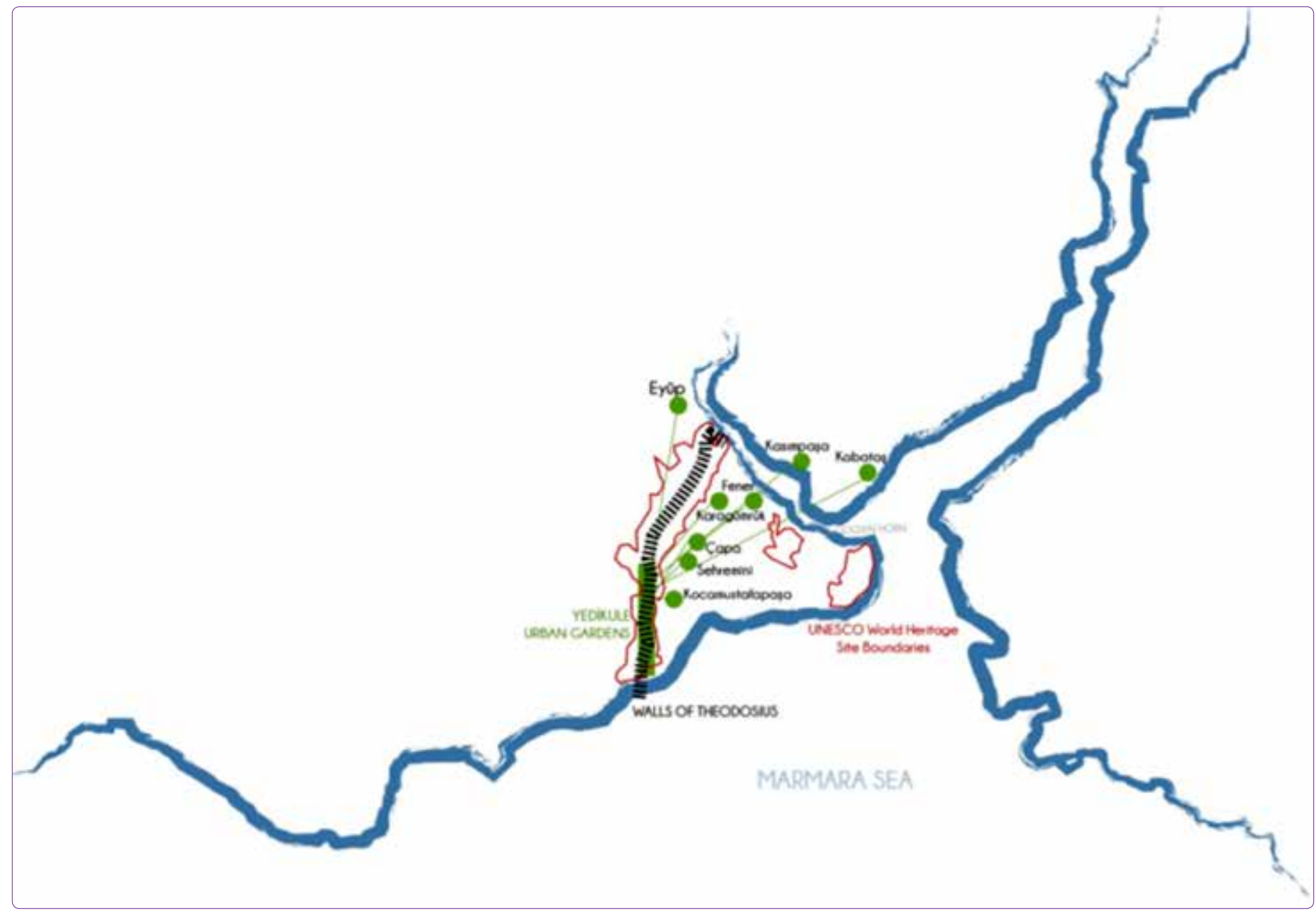

Figure 4. Map showing the location of Yedikule Urban Gardens and Theodosius Walls, boundaries of UNESCO World Heritage Site of Istanbul and distribution points of surplus coming from Yedikule within Istanbul (Prepared by Authors, with the help of information coming from [URL-6]).

1900s. However these uncontrolled variations caused an inevitable decay in the overall quality and impact of the green belt.

Located within the boundaries of Fatih district as the property of Fatih Municipality, Yedikule Urban Gardens continued to contribute the need for food production in local and neighborhood scale as well as their wider scale networks of Istanbul from Byzantine times. ${ }^{28-30}$ Gardeners still plant and harvest within the boundaries of their individual rented plots in Yedikule Urban Gardens at the present. The municipality defines the borders of the garden-plots and rent them to those who were capable of tending to the land. ${ }^{31}$ Connected to this organic pattern of ownership, it is difficult to define the exact number as well as borders of the urban gardens in Yedikule. ${ }^{32,33} \mathrm{How}$ ever, it is known that an ordinary urban garden in Yedikule

\footnotetext{
${ }^{28}$ Kaldjian, 2004, s.290.

${ }^{29}$ White et. al., 2015, s.7.

${ }^{30}$ Shopov et al., 2013, s.37.
}

\footnotetext{
31 Tanyeri-Erdemir, 2009, s.6.

${ }^{32}$ Kaldjian, 2004, s.295-296.

${ }^{33}$ Shopov et al., 2013, s.35-37.
}

was nearly 10-20 hectares, about the size necessary for a household no more than the members of a family of five to meet their basic needs of livelihood and a typical gardener who is usually a low income levelled immigrant support households, sustain land, protect communities, maintain traditions and beautify landscapes with the help of his/her local techniques. ${ }^{34}$

Production within the Yedikule Urban Gardens provides relations with a number of local neighborhoods as well as a lot of retail markets and city bazaars such as Fatih, Kocamustafapasa, Karagümrük and Sehrimini. This connection creates a sort of socio-economic and commercial network of the daily life (Figure 4) [URL-6]. ${ }^{35}$ According to the gardeners, in October and November gardens in Yedikule are full of agricultural products ready to be collected. ${ }^{36}$ The operation and collection of products of today's urban gardens of Yedikule were similar to the traditional ways of

\footnotetext{
${ }^{34}$ Kaldjian, 2004, s. 286-287. $\quad{ }^{36}$ Tanyeri-Erdemir, 2009, s.6.
}

${ }^{35}$ Kaldjian, 2004, s. 291-293. 


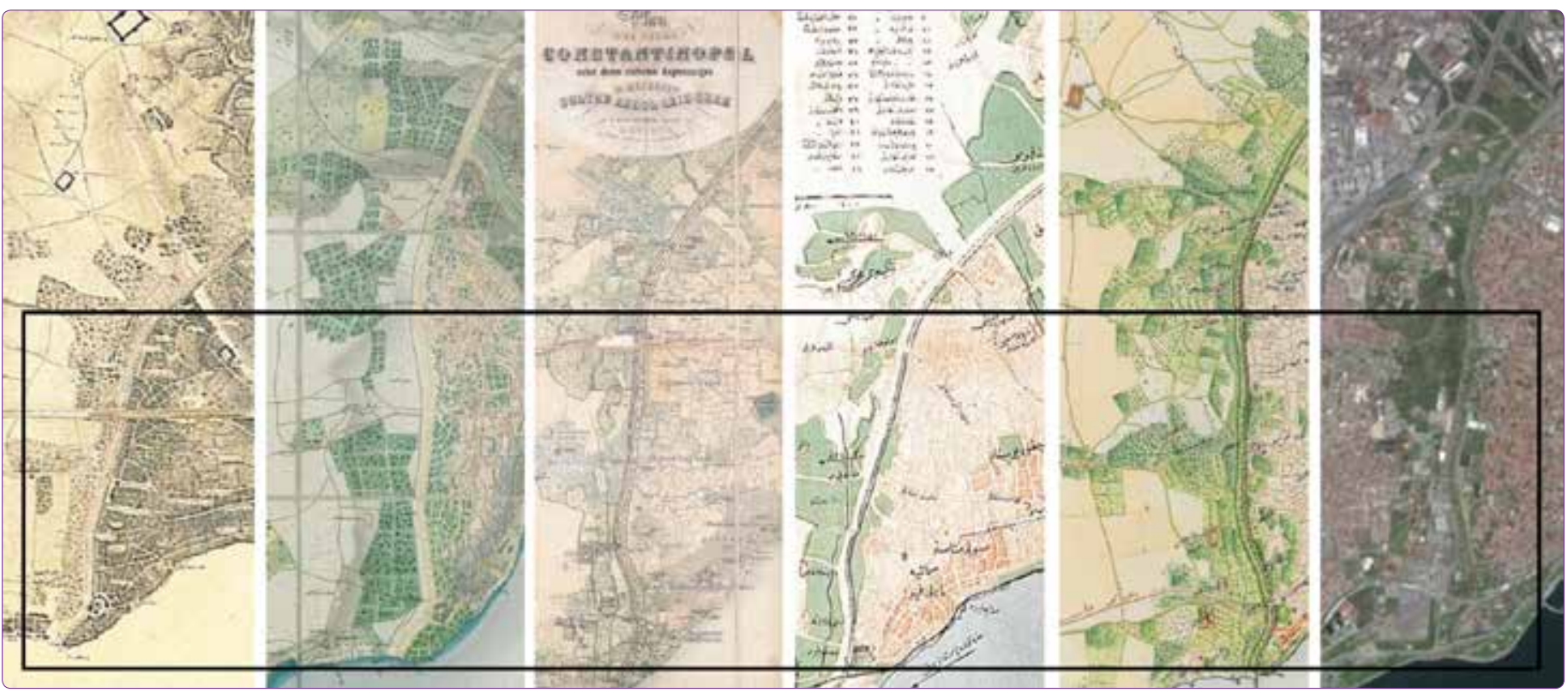

Figure 5. Maps of Istanbul showing Yedikule Urban Gardens prepared by Moltke, 1852 (Kayra, 1990: 110); Muhendishane-i Humayun, 1845 (Koçak et al., 2013: 42); Stolpe, 1863 (Kayra, 1990: 116); Magazine Malumat, 1896 (Kayra, 1990: 133); Hubner, Period of Abdulhamid (Koçak et al., 2013: 36) and Google Earth, 2014 respectively.

the past. Even the diversification of crops was almost the same especially the famous Yedikule lettuce (lactuca sativa) as well as cabbage, beets, carrots, onions and etc. ${ }^{37-39}$ According to researchers, this continuity in the plantation and watering techniques was due to the remaining edifices especially old irrigation and channel systems built on the bottom of the walls [URL-16].$^{40}$ Hence, Yedikule Urban Gardens as a significant cultural landscape presents important information regarding the agricultural technology of Byzantine and Ottoman times, as well as the relations between human beings and how they treat nature in multiple layers. ${ }^{41,42}$

\section{Destruction of Yedikule Urban Gardens: Current Regulations, Big Troubles and Conservation Efforts}

Urban Istanbul has expanded with a rapid and irrepressible process since 1970 s as a result of the continuing migration from rural Anatolia and growing industrial land uses. This rapid expansion in the physical urban environment and population were associated with political disruption and speculative investment in housing development as well as the idea of "modernization" and "globalization". These main trends in economy politics have challenged the longlasting characteristics of the city scape with new types of residential patches and over-scale transportation passageways. Natural areas in Istanbul have inevitably affected con-

\footnotetext{
${ }^{37}$ Kaldjian, 2004, s. 295.

38 Shopov et al., 2013, s.36.

${ }^{39}$ Ricci, 2008, s.67.
}

\footnotetext{
${ }^{40}$ Kıvılcım Çorakbaş et al., 2014, s.10.

${ }^{41}$ Yedekçi Arslan, 2015, s.89.

${ }^{42}$ Shopov et al., 2013, s.34.
}

nected to this urbanization and growth tendencies. Hence, urban gardens of the city that satisfied not only the ecological and economical amenities of life, but also social needs have started to disappear. The city has faced the challenges of cultural conservation, economic development and social inclusion. This has gradually destructed and transformed the urban open areas into different uses for the "development" of new communities in recent decades.

Because of inadequate care and attention paid to these rare sites in the city, Yedikule Urban Gardens were neglected, filled with rubbish and then became a place of crime and illegal activities as it can be followed from the maps and photographs ordered in a chronological way (Figure 5-8). The quality of open space along Theodosius Walls is low due to the heavy traffic and inappropriate facilities of infrastructure. These are the main reasons neither local nor foreign tourists did not visit the site at all. ${ }^{43}$ As a consequence, Yedikule Urban Gardens have started to disappear with unsuitable measures taken by governmental authorities in the recent past.

To elaborate, the change in Yedikule Urban Gardens started with the declaration of this site as a "renewal area" in the September of 2006. ${ }^{44,45}$ This decision was completely

\footnotetext{
${ }^{43}$ Kıvılcım Çorakbaş et al., 2014, s.31.

44 Yedikule Urban Gardens were declared as "renewal area", as identified in 5366 numbered "Law on the Conservation through Renewal and Preservation through Use of Decrepit Historical and Cultural Assets", with 2006/70 numbered decision of Fatih Municipal Assembly in 09.06.2006. They were then identified as "second degree
}

renewal area" with 1327 numbered decision of Istanbul Metropolitan Municipal Assembly in 13.07.2006, this decision was announced by $2006 / 10961$ numbered decision of the Council of Ministers in 13.09.2006 and finally the decision became valid following its presentation in 26318 numbered official gazette.

Koca, 2014, s.58 


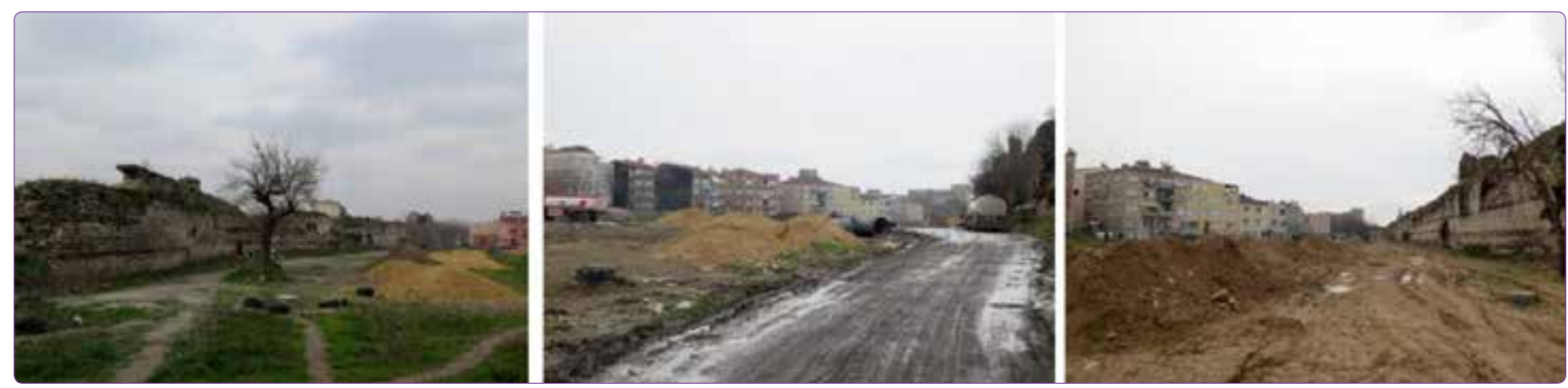

Figure 6. Destruction of Yedikule Urban Gardens (Personal Archive of E.Durusoy).

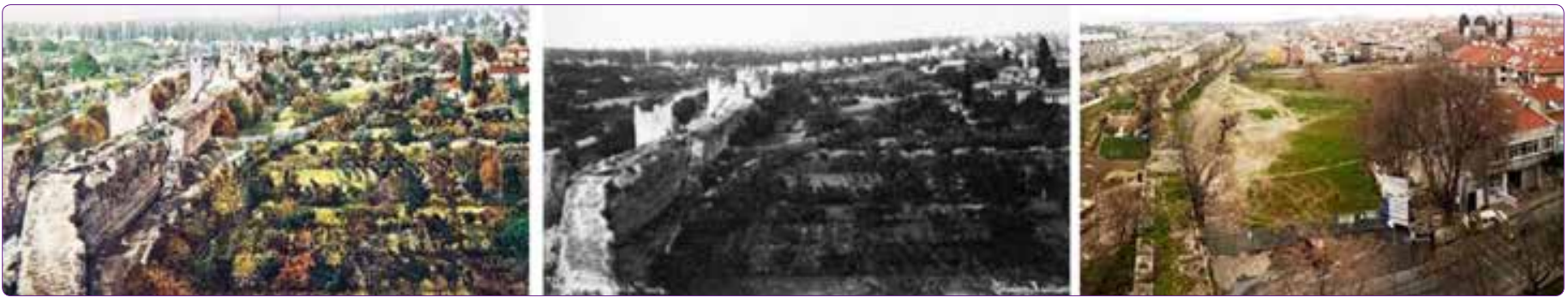

Figure 7. Yedikule Urban Gardens from the same point of view (Left) Yedikule Urban Gardens in 1909 [URL-7] (Middle) Yedikule Urban Gardens in 1900ies [URL-8] (Right) Yedikule Urban Gardens in 2014 [URL-8].
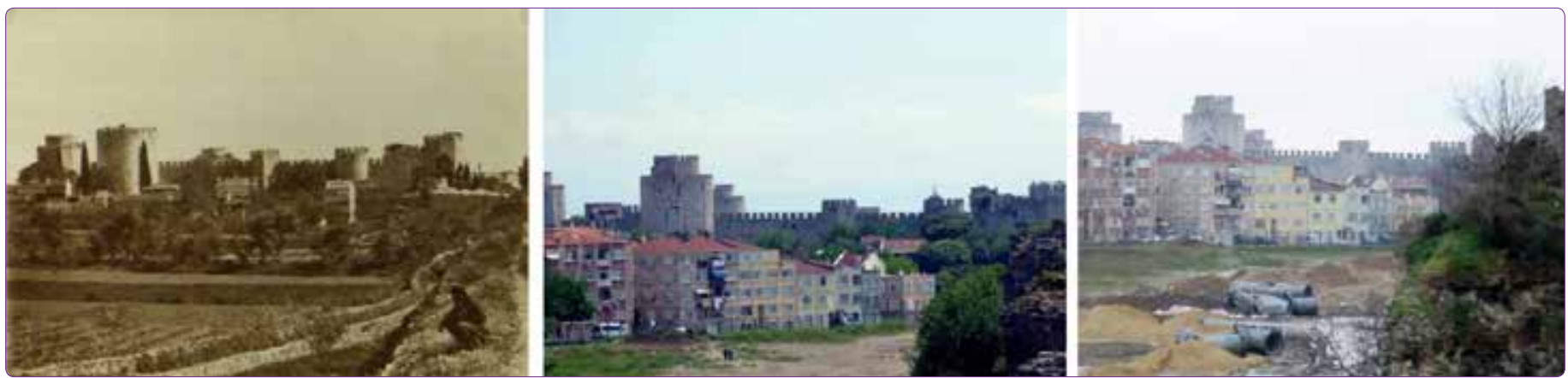

Figure 8. Yedikule Urban Gardens from the same point of view (Left) Yedikule Urban Gardens in 180ies [URL-9] (Middle) Yedikule Urban Gardens in 2013 (Personal Archive of E. Durusoy) (Right) Yedikule Urban Gardens in 2015 (Personal Archive of E. Durusoy).

contradictory with the $1 / 1000$ scale Conservation Implementary Development Plan. ${ }^{46}$ Following the adoption of decision of "renewal", bulldozers of Fatih Municipality came to the site and demolished two urban gardens, which were the building blocks numbered 1166 of lot 35 and numbered 1265 of lot $8 .^{47}$ They also damaged Theodosius Walls by removing nearly one meter of soil off their basements. ${ }^{48}$ However, it is known that the illegal construction activities within the same area started before that decision with Yedikule Villas-four story luxury residences.

After four years of stagnation, Fatih Municipality prepared a thematic urban park project entitled "Recreation Implementation Project for Yedikule" just next to Yedikule

\footnotetext{
${ }^{46}$ Yedekçi Arslan, 2015, s.91. $\quad{ }^{48}$ White et. al., s8.

${ }^{47}$ Kıvılcım Çorakbaş et al., 2014, s.10.
}

Villas in 2010. The project forecasts the replacement of majority of Yedikule Urban Gardens with a recreational and artificial green area extending approximately seven kilometers along the walls of Theodosius [URL-10 and URL-11]. However, it is clear that this 70,000 square meter park project is not possible according to 6848 numbered "Urban and Historic Site Areas of Historic Peninsula" decision of 1995, 101 numbered "Management Plan of Historic Peninsula" decision of 2011, 2863 numbered "Law on the Conservation of Cultural and Natural Property" as well as the "Green Cities Declaration of United Nations" Environment Programme" that was signed by Istanbul in 2005 [URL-12]. ${ }^{49-51}$ By covering the area with infertile soil,

\footnotetext{
${ }^{49}$ Kaldjian, 2009, s.11.

${ }^{50}$ Tarihi Yarımada Yönetim Planı, 2011, s.101.

512863 Numbered Law on the Conservation of Cultural and Natural Property, 1983
} 


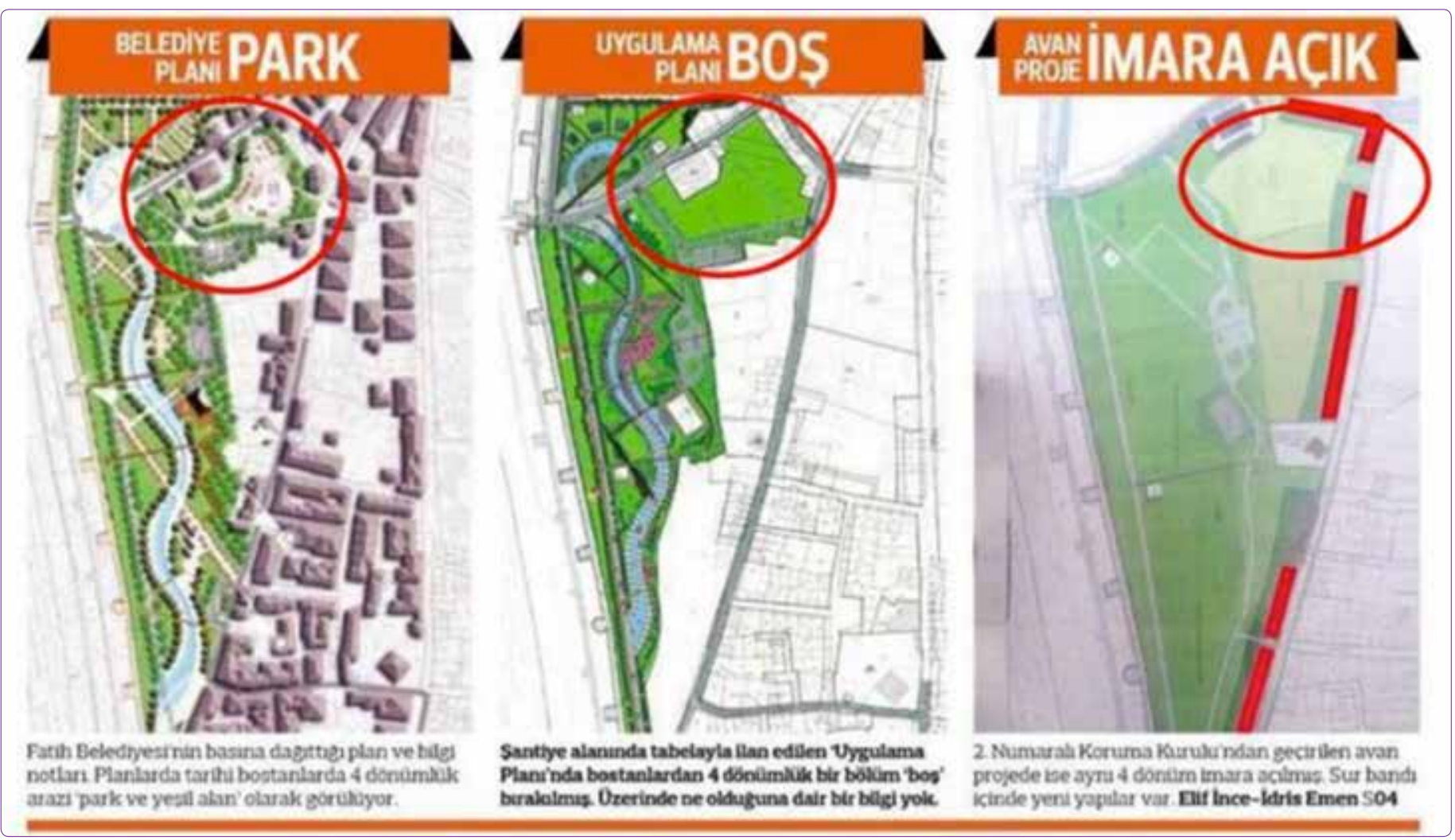

Figure 9. Municipality Plan as a park, Implementation Plan as an empty space and the First Draft as a plan open to development of “Recreation Implementation Project for Yedikule" [URL-10].

the park project is further spoiled the long-lasting environmental, historical, documentary, aesthetic and artistic, social and cultural, technologic, functional and economic values of Yedikule Urban Gardens. The traces of a unique ecosystem of houses, barns, gardens and resources of Ottoman agricultural technology have been erased day by day.

The idea of planning this kind of a park welcomed by most of the inhabitants and gardeners with the sense of the increase in the values of their own properties at first. ${ }^{52}$ However, the project was met by massive disapproval from professionals including environmentalists, historians, city planners, architects, artists and academics who have realized the impossibility for a low-income urban gardener to enter within the above-mentioned designed landscapes and pay high wages as seen in the case of several similar renewal areas of Istanbul. ${ }^{53,54}$ This is mainly because the project does not address and object to conserve the heritage of urban agriculture, old traditions and the living culture of the site. Rather it involves the removal of one of

\footnotetext{
52 Yedekçi Arslan, 2015, s.94.

53 Yedekçi Arslan, 2015, s.93.

${ }^{54}$ Further information on the renewal projects of Istanbul such as Sulukule and Tarlabaşı cases can be reached from https://inuraistanbul2009.files. wordpress.com/2009/06/unesco-sulukule-2009.pdf and http://www.tarlabasi360.com/.
}

the last surviving urban gardens of Istanbul. Nonetheless, the project was undertaken once more in the beginning of the summer of 2013 with the following announcement of Mustafa Demir-the mayor of Fatih Municipality: "We will clean up this area and make a park so people who live in this neighborhood can walk and rest by the city walls" [URL-13]. Thankfully, the construction activities were stopped by the official denials of Archaeology Museums of Istanbul. .5 $^{5}$

However, after a short break, Istanbul Metropolitan Area Municipality once again began construction in Yedikule with the artificial pool in November of $2014 .{ }^{56}$ Moreover, the recognition of three different plan renderings of the single project that paved the way towards construction of new residential buildings as well as a number of restaurants, coffee shops, playgrounds, car parks and parking lots (Figure 9 and Figure 10) [URL-10]. This move caused a number of serious protests and opposing developments in forms of new social groups to protect the area from improper urban development (Figure 11). ${ }^{57}$ Especially "Istanbul Branch of Archaeologists' Association" (Arke-

\footnotetext{
${ }^{55} 2863$ Numbered Law on the Conservation of Cultural and Natural Property, 1983. According to the 2863 numbered law, excavations in these kinds of areas should be

made according to consultation of Archaeological Museums.

56 White et. al., s8-9.

White et. al., s9.
} 

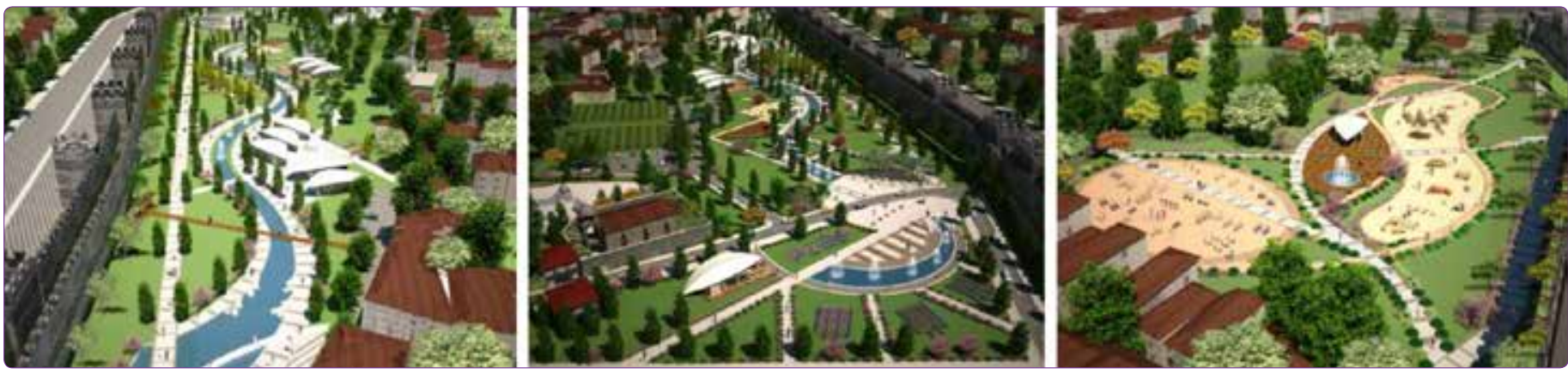

Figure 10. Visuals and details of "Recreation Implementation Project for Yedikule" [URL-11].

ologlar Dernegi Istanbul Subesi) as one of the main bodies composed of a number of Turkish archaeologists who all dispute the destruction of Yedikule Urban Gardens for developing a new community proposed a number of refusal reports by underlining the improper method of excavations taken place in the area and realized several actions focused on local communities to raise public awareness [URL-14]. "Yedikule Gardens Protection Initiative" (Yedikule Bostanlari Girisimi), another active group, has also worked on different projects for people to come and learn the living traditions and urban agriculture with the help of forums, exhibitions, courses and other activities with the help of experts and institutions from different disciplines [URL-15]. In addition to these working bodies, the contradictory process of Yedikule Urban Gardens have interested and attracted researchers from abroad such that several workshops were carried by Harvard University and RWTH Aachen University with supports of Kadir Has University, Okan University, Istanbul Technical University and Bilkent University [URL-6, URL- 16 and URL-17]. A signature campaign was also initiated under the theme: "Historic mission and traditional function of Yedikule Urban Gardens should be conserved; Yedikule Urban Gardens should remain for urban agriculture." to advocate for UNESCO regarding the protection of the Theodosian Walls and gardens associated [URL-18].

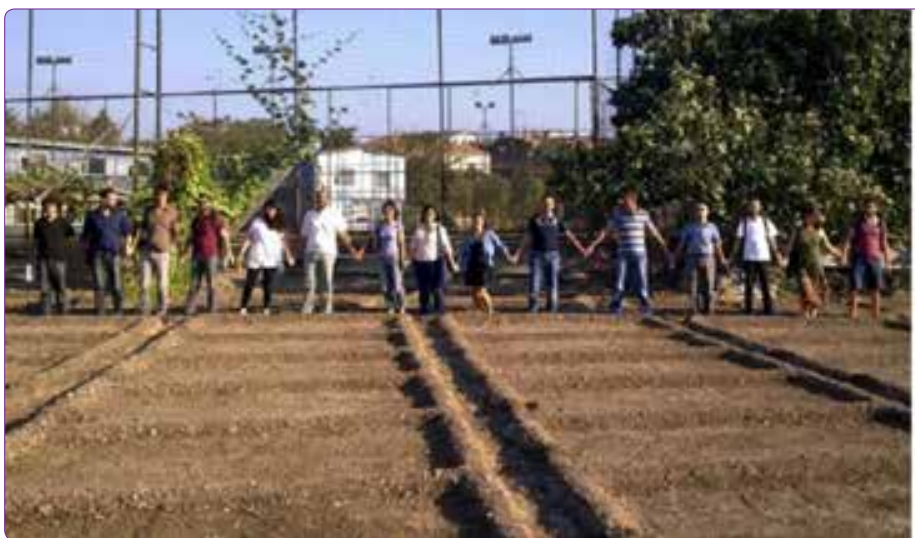

Figure 11. Protests for conserving Yedikule Urban Gardens [URL-19].
These initiatives all aim to increase awareness of the society and encourage people to vitalize the site. With their efforts and voluntary works, Yedikule Urban Gardens is now transformed into a social gathering place that inspired new forms of public activities [URL-15]. These collective recreational movements were firstly started with a scarecrow making workshop by using life-expired clothes. This first workshop that was intended to take the permanent attention of passengers crossing Yedikule Urban Gardens then continued with a number of events having creative ideas (Figure 12). For instance, people of all ages, gender and skill have tried to contribute for the perpetuation of the gardening culture of Yedikule in the recently built "Yedikule Bostan School" (Yedikule Bostan Okulu) where seminars and training sessions on agriculture, planting, watering and collecting have been organized. In addition, theatrical art performances have taken place with the participation of various artists and performers around the world. Archaeobotany walks have realized for participants to be informed on the plants and unusual species being existed in Yedikule Urban Gardens. Special workshops on sculpture, t-shirt printing, cartoon drawing etc. have initiated for children. Thematic festivals such as "Lettuce Feast" (Marul Bayramı) and "Terra Madre Day" (Toprak Ana Günü) that were indeed celebrated in the past on specific days of the year have revived.

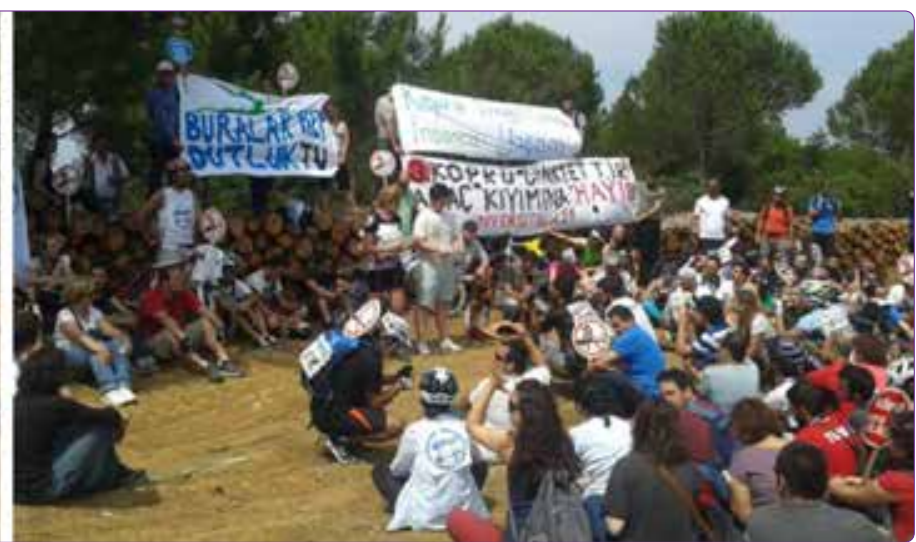




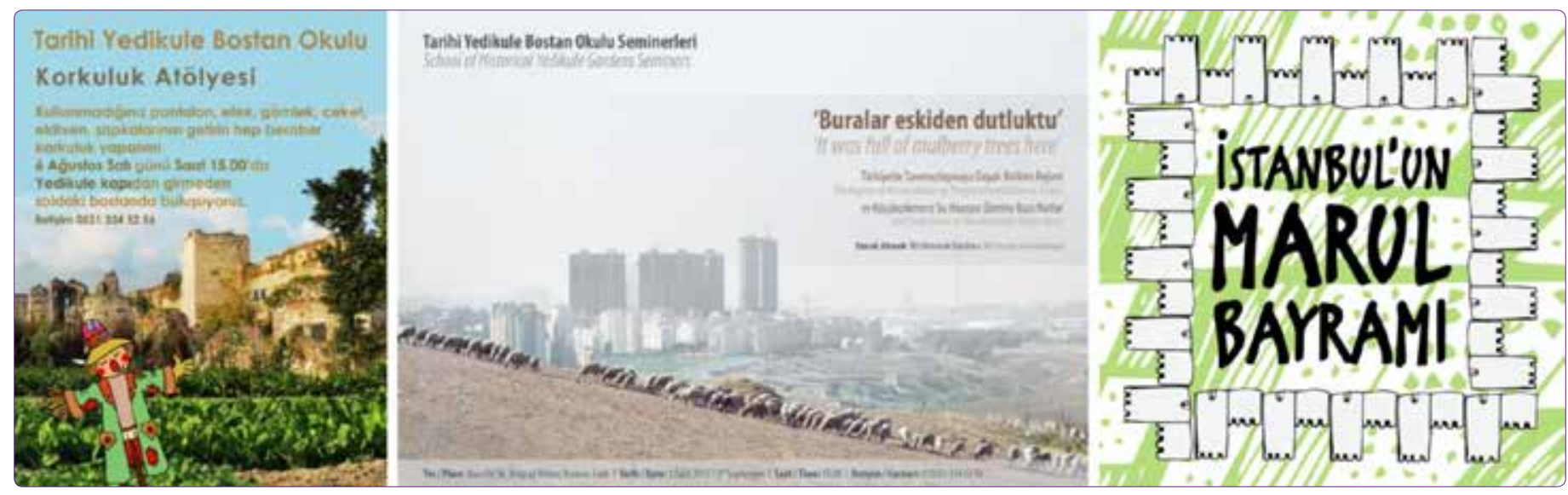

Figure 12. Selected voluntary works and public activities realized in Yedikule Urban Gardens to increase awareness of the society, encourage people and vitalize the site [URL-15].

\section{Discussion and Conclusion}

Yedikule Urban Gardens along Theodosius Walls presents a deep-rooted, urban agricultural tradition in Istanbul. Together with their social, cultural, environmental and economic benefits Istanbul retains urban gardening"bostancllık" tradition and culture by enabling production of various agricultural products in contrast to many other cities around the world where urban agriculture are being re-invented. ${ }^{58}$ Hence, by facilitating diversity in urban agriculture due to its convenient geography and environmental conditions especially the water and soil resources, Istanbul has luckily preserved the evidences of its fertile Yedikule Urban Gardens up to the present times. Nonetheless, in a day where the most civilized and modern cities from all over the world are trying to integrate urban gardens into their urban built environment for establishing ecological, social and cultural balance within their own cities, a living and functioning model has tried to be destroyed in Istanbul.

Sustainable conservation of cultural and natural heritage has been a major task for governments and local authorities all over the world with the recognition of the Convention Concerning the Protection of the World Cultural and Natural Heritage of UNESCO [URL-1]. Since that period of time, great efforts have been made towards sustainable preservation and management of cultural heritage all over the world. Although the long-lasting signs of urban gardening tradition in one of the fifteen world heritage sites of Turkey - "Historic Areas of Istanbul" is still exist and can be used as a chance to increase environmental product variability, quality of living area, economic diversity and social relations among people for the case of Istanbul; governmental recognition of greeneries has mostly concentrated on development of 'creative' ideas in forms

\footnotetext{
${ }^{58}$ Kaldjian, 2004, s.302
}

of artificial orchards, floating green grounds and/or hobby gardens which offer residents to rent small plots in unsuitable parts of cities by promising them to create their own gardens (Figure 13) [URL-20].

At this point, rather than artificial greeneries, urban gardens should be sustained to future within their historical contexts, physical infrastructures and social networks. In this sense, with a comprehensive conservation project including combined phases of rehabilitation and a vibrant and respective urban design proposal including not only the urban gardens but also Theodosius Walls as crucial resources, Yedikule Urban Gardens can be carried to a better state. By combining tangible and intangible contexts with long-term policies and programs to transmit their widespread benefits to public, the precious identity of Yedikule Urban Gardens can easily be revived. To achieve this, a well-functioning communication network between well-informed urban gardeners, conscious inhabitants, associated institutes as well as local authorities should be set much more responsively. This is crucial for the Yedikule Urban Gardens for them to not end up as in the most cases of urban transformation projects of Istanbul.

The aim of this paper has been to shed new light on the perspective and management of urban gardens in terms of policy decisions, urban planning legislations and conservation politics through the case of Yedikule Urban Gardens. However, a recent term Urban Green Commons (UGCS) is also worth mentioning for the concluding words of this study to trigger possible future research on this topic. This term basically refers to the urban open and green areas on which agriculture and farming activities occur such as the urban gardens, community gardens and allotment gardens. Although they are classified in terms of the property rights and management systems, they share common characteristics in their development. UGCs emerge and are maintained through bottom-up and community-based initiatives. ${ }^{59}$ 

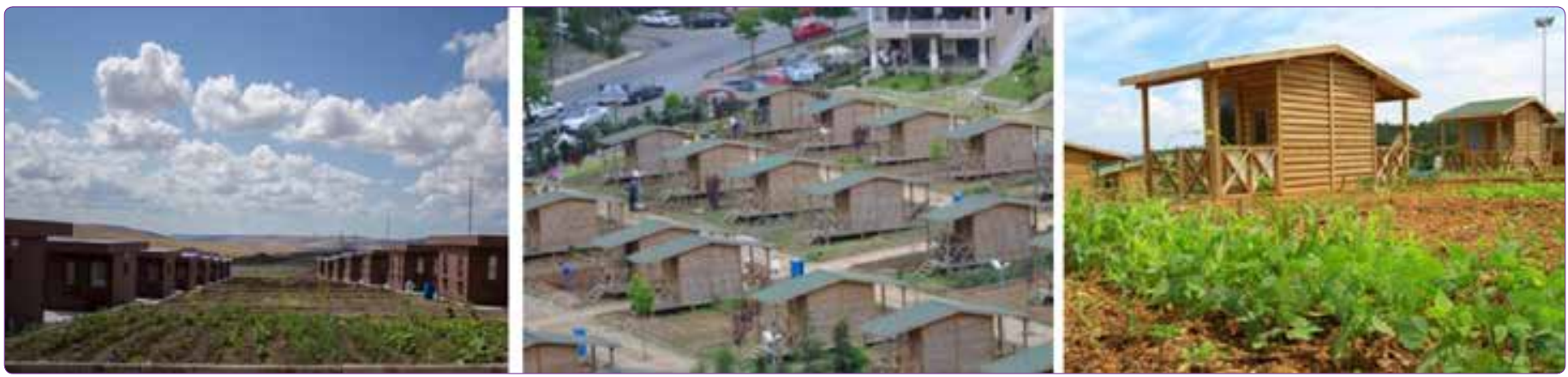

Figure 13. Hobby gardens of Arnavutkoy, Beykoz and Sultangazi; respectively [URL-21].

These urban areas are defined as a significant part of public realm in cities. They have the potential foster ecological, societal and psychological well-begins of both cities and societies through civic participation and collective production in open, green, productive and common spaces. The main proposals for the policy makers and urban planners claim that they should address the significance of these gardens for their ability to create a new understanding of ownership and use rights in cities, their ability to bring people together in a highly culturally diversified world. ${ }^{60}$ Moreover, these places as urban and community gardens support the local economies in terms of agricultural production. Besides this being a trendy issue in developed countries, it cannot be overlooked that they rebound people and provide them alternative financial instruments worldwide [URL-22].

For instance, one of the well-known forms of UGCs is Public-Access Community (PAC) gardens. They are being collectively managed urban green areas open for anyone at any time interested to learn gardening and food cultivation. ${ }^{61}$ As crucial place making initiatives, they provide a learning environment and promote cultural integration at different scales. From the most popular examples among the several PAC gardens in Berlin, Bürgergarten Laskerwiese, Rosa Rose Garten and Ton Steine Garten and Prinzessinnengarten promote sustainable ecosystems with cost effective options by bringing people together. ${ }^{62,63}$ Thanks to their self-generated physical integrity, information sharing platforms, social structures and common interests, they further foster sense of place by broader knowledge and everyday practices on gardening.

Yedikule Urban Gardens can be classified under the concept of urban green commons as well. Besides its deeprooted history and recent transformation threats, these gardens constitute a section of public realm in Istanbul and have the potential to enrich communal bound and ecological sustainability. However, the emergence of similar urban

\footnotetext{
${ }^{59}$ Colding et al. 2013, s. 1046.

${ }^{60}$ Colding et al., 2012, s. 159-161.
}

land uses defending the collective agricultural food production and public spaces of highly urbanized cities poses an important research topic as well. These green commons have come into the scene especially after Gezi Protests in Turkey in 2013. The neighborhood forums led to some permanent neighborhood initiatives that take care of their close environment both in physical and social terms. An amount of these initiatives have transformed neighborhood gardens (mahalle bostanı) most of which are still functioning today. The originalities of the UGC concept in the Turkish context are these gardens' creation and maintenance by local communities, and their land permits and property right issues. These areas seem to support solidarity among communities adding to their ecological, social, economic and psychological benefits. Therefore, further studies should develop on this very unique perspective towards UGCs by keeping in mind the necessity to preserve the old values as well as create the new opportunities.

\section{References}

2863 Numbered Law on the Conservation of Cultural and Natural Property (1983) Kültür ve Tabiat Varlıklarını Koruma Kanunu, Kültür ve Turizm Bakanlığı.

Başer, B. and Eşbah Tunçay H. (2010) "Understanding the Spatial and Historical Characteristics of Agricultural Landscpaes in Istanbul”, ITU A-Z, Vol.7, Num.2, pp. 106-120.

Bendt, P.; Barthel, S. and Colding, J. (2012) "Civic Greening and Environmental Learning in Public-Access Community Gardens in Berlin", Landscape and Urban Planning, Vol.109, pp.18-30.

Colding, J.; Barthel, S.; Bendt, P.; Snep, R., Knapp W. and Ernston, H. (2013) "Urban Green Commons: Insights on Urban Common Property Systems", Journal of Global Environmetnal Change, Vol.23, Issue.5, pp. 1039-1051.

Colding, J. and Barthel, S. (2012) "The Potential of 'Urban Green Commons' in the Resilience Building of Cities", Ecological Economics, Vol.86, pp. 156-166.

İstanbul Büyükşehir Belediyesi (2011) Tarihi Yarımada Yönetim Planı, İstanbul Sit Alanları Alan Yönetimi Başkanlığı, İstanbul.

Kaldjian, P. J. (2004) "Istanbul's Bostans: A Millennium of Market Gardens", Geographical Review, Vol. 94, No. 3, pp. 284-304.

Kaldjian, P. J. (2009) "Harvesting the Past for a Sustainable Fu-

\footnotetext{
${ }^{62}$ Bendt et. al., 2003: 27-29. $\quad{ }^{63}$ Colding et. al., 2013: 161.
} 
ture: Reviving Istanbul's Bostans", Annex, Vol.4-Migrating Gardens, pp.10-11.

Kayra, C. (1990) İstanbul Haritaları, Ortaçağdan Günümüze: Maps of Istanbul from the Middle Ages to Present Day, Istanbul, Sınai Kalkınma Bankası Yayınları.

Kıvılcım Çorakbaş, F., Aksoy, A, and A., Ricci, A. (2014) A Report of Concern on the Conservation Issues of the Istanbul Land Walls World Heritage Site: With a Special Focus on the Historic Yedikule Vegetable Gardens (Yedikule Bostanları), A Report Presented to UNESCO World Heritage Centre, Republic of Turkey-Ministry of Culture and Tourism World Heritage Sites Office and Istanbul Site Management Directorate.

Koca, A. (2014) "Güncel Dosya: Bostanlar", Yapı, Vol.386, pp.5864.

Koçak, Y.; Ademoğlu, A.; Beşli, A.; Eraslan, Z. and Akçay, Y. (2013) Sultan II. Abdülhamid Devri Harita ve Planlarında İstanbul, Istanbul, Istanbul Büyükşehir Belediyesi Kültür A.Ş. Yayınları.

Koçu, R. E. (1963) "Bostan”. Ed.: Istanbul Ansiklopedisi ve Nesriyat Kollektif Sirketi (editors) Istanbul Ansiklopedisi, Husnutabiat ve Ercan Matbaası, Vol.6, pp.2971-2973.

Ricci, A. (2008) "İstanbul'da Manevi Kültürel Miras: Kara Surlarının Bizans Bahçeleri", Ed.: Ş. Memiş and F. Sadırlı (editors) İstanbul 2010 Avrupa Kültür Başkentinin Kalbi Tarihi Yarımada: 3. Uluslararası Tarihi Yarımada Sempozyumu Tebliğler Kitabı, İstanbul, Eminönü Belediyesi\&Haliç Belediyeler Birliği, pp.66-67.

Shopov, A. and Ayhan, H. (2013) "Osmanlı Istanbul'unda Kent İçi Tarımsal Toprak Kullanımı ve Dönüsümleri: Yedikule Bostanları", Toplumsal Tarih, Vol.236, pp.34-38.

Tanyeri-Erdemir, T. (2009) "Chasing Calves in Istanbul: The City, Its Walls and Orchards", Annex, Vol.4-Migrating Gardens, pp.6-7.

UNESCO (2009) World Heritage Cultural Landscapes: A Handbook for Conservation and Management, Paris, UNESCO World Heritage Center.

White, C., Shopov, A. and Casson, A. (2015) "Heritage under Threat: Saving the Ancient Gardens of Istanbul, Turkey", The SAA Archaeological Record, Vol.15, Num.1, pp.7-10.

Yedekçi Arslan, G. (2015) "Tehdit Altında Bir Miras Alanı: Istanbul Yedikule Bostanları”, Mimarist, Vol.52, pp.88-95.

\section{Internet Sources}

URL-1. http://whc.unesco.org/archive/convention-en.pdf (27.08.2015).
URL-2. http://www.uskudarli.com/haberdetay.asp?ID=1402 (27.08.2015).

URL-3. http://listelist.com/eski-istanbul-semt-fotograflari/ (27.08.2015).

URL-4. http://www.skylife.com/tr/2014-05/mikelanj-in-cagdasibir-osmanli-matrakci-nasuh (27.08.2015).

URL-5. http://modernfarmer.com/2013/08/istanbuls-disappearing-urban-farms/ (27.08.2015).

URL-6. http://isites.harvard.edu/icb/icb.do?keyword=k94076\& pageid=icb. page577191 (27.08.2015).

URL-7. http://www.inenart.eu/?p=13096 (27.08.2015).

URL-8. http://serbestiyet.com/Yazarlar/sur-bostan-kopru-132060 (27.08.2015).

URL-9. http://www.doaks.org/news-events/newsletter/newsarchives/tyler-fellows-in-residence-sopov (27.08.2015).

URL-10. http://www.fatihhaber.com/fatihhaber/yedikulebostan-radikal.htm (28.08.2015).

URL-11. http://www.fatih.bel.tr/icerik/7514/fatihe-dev-park/ (27.08.2015).

URL-12. http://www.fundacionciudad.org.ar/pdf/SanFranciscoAccords2005.pdf (27.08.2015).

URL-13. http://www.radikal.com.tr/turkiye/bostan_cevresi_ kamu_yarari_icin_imara_acildi-1147050 (27.08.2015).

URL-14. http://arkeologlardernegi.org/?s=yedikule (27.08.2015).

URL-15. http://yedikulebostanlari.tumblr.com/ (27.08.2015).

URL-16. http://www.la.rwth-aachen.de/PDF/120724_TheodosianWalls_and__Agriculture_RWTH_standard.pdf (27.08.2015).

URL-17. http://www.la.rwth-aachen.de/PDF/140213\%20TheodosianWalls_standard.pdf (27.08.2015).

URL-18. $\quad$ https://www.change.org/p/fatih-belediyeba \% C5\% 9Fkan\% C4\%B 1-mustafa-demir-yedikulebostanlar\%C4\%B1-n\%C4\%B1n-tarihi-misyonu-ve-geleneksel-fonksiyonu-korunsun-yedikule-bostanlar\%C4\%B1tar\% C4\% B 1 m-ala n \% C 4\% B 1-olarak-kals \% C 4\% B 1 n (27.08.2015).

URL-19. http://www.yesilist.com/cms.php?u=yedikule-de-sondurum-1182\&id=1182 (27.08.2015).

URL-20. http://www.ocs.polito.it/seminar_IP2013/zeynep_yerliyurt.pdf (27.08.2015).

URL-21. http://www.listemis.com/istanbul-hobi-bahcesi/ (27.08.2015).

URL-22. http://xxi.com.tr/6250/yunanistanda-ekonomik-krizeyesil-cozum/ (27.08.2015). 